\title{
The Persistence of Society-Driven Engagement in Swedish Cinema: A Locational Analysis, 1936-2016
}

\begin{abstract}
This article underlines the importance of grass-roots civic society involvement in cinema exhibition in villages and towns in Sweden throughout the twentieth century. We investigate geographic patterns of cinema exhibition and ownership over time in a mixed rural cum (post)industrial region in the central part of Sweden known as Bergslagen. In a systematic comparison across temporal and geographic entities our analysis details the extent of civic society engagement in cinema. Our analysis suggests that civic societies contributed to the high number of cinemas in rural and small town Sweden as well as to the persistence of a surprisingly evenly distributed and decentralized pattern of cinema exhibition up until this day.
\end{abstract}

\section{Keywords}

cinema history; New Cinema History; location analysis; Swedish cinema; film exhibition

Fresh empirical work on rural cinema, travelling exhibitors, exhibition in multipurpose venues, in non-commercial cinema circuits and in other formats than $35 \mathrm{~mm}$ feature programs offers a historically grounded,richvariety oftheconditionsforcinemagoinginpartsofEurasia,NorthaswellasSouthAmerica,and Australia. ${ }^{1}$ LeifFurhammar'sstandardoverviewofSwedishfilmhistoryisanextraordinarypioneeringstudywith manymerits,yetbygivingprecedencetoa metropolitanperspective whilediscussingfilmexhibition, choosesa rather narrow path for this section of its historical narrative. From the early 1930s, it explicates, three to four larger companies dominated thenational cinema sector as measured in revenues and in number of screenings per week per cinema. The companies operated from the capital city of Stockholm and their cinema chains included cinemas in Sweden's cities and larger towns. ${ }^{2}$ Besides the chains controlled by these major, vertically integrated film corporations, Furhammar doesn't fail to mention more marginalised cinemas and chains of cinemas - owned by smaller companies as well as workers and temperance societies. However, in theoverview, thechronologicalhistoricalnarrativeisorganisedin adivisionof:1)theeconomicconditionsinStockholmand 
2) the rest of the country. This is highly problematic since it is fair to assume that conditions of cinema exhibition vary according to interrelated socioeconomic, demographic, cultural in addition, geographic features of different localities in Sweden. ${ }^{3}$

Challenging the marginalised status of cinema outside of Stockholm, ethnographic studies have confirmed the importance of cinema to everyday life in rural areas. ${ }^{4}$ Furthermore, case studies of exhibition in the counties of Västernorrland and Jämtland, both situated in the scarcely populated North of Sweden, reveal the existence of cinema even in very small and remote locations. ${ }^{5}$ From the start of travelling film exhibition in the late nineteenth century and to the present, community venues owned by grass roots, voluntary societies, in particular those tied to the workers movement and the temperance movement, have been used for the exhibition of film. ${ }^{6} \mathrm{~A}$ comprehensive historical documentation of cinema in the far Northern county of Västernorrland shows a varied structure of cinema ownership, and competition for access to community venues in which to run cinema operations. Privately owned touring companies hired space in the society-owned community venues, local societies with their own venue registered cinema companies; both private companies and voluntary societies could lead single operations, they could also be part of a commercial cinema chain or a society-driven distribution circuit. ${ }^{7}$ The significant presence of cinema outside of Stockholm and its reliance on society-owned community venues, traditional commercial operations and grass roots engagement, suggests a variation of the conditions of exhibition. It also suggests that the interests and actions of the ideology-driven, society-run cinema sector and in particular its largest proponent, the workers movement, is key to understanding Swedish cinema history in non-metropolitan localities.

In this study, we investigate geographic patterns of cinema exhibition and ownership over time in a mixed rural cum industrial region in the central part of Sweden known as Bergslagen. Thus, the study relies on a systematic comparison across temporal and geographic entities, across communities and territories, by including locations of different patterns of settlement and degrees of urbanisation. We examine relations between spatial features of localities (including population density and distance to other locations), ownership and size of cinemas, and changes of these parameters over a long time-period, from 1936 to 2016. The overall aim is to contribute to a nuanced understanding of the conditions and variations of historical cinema exhibition in what Furhammar in his Stockholm-centric perspective conflated into one entity, Stockholm's 
Other, the rest of the country. With a focus on cinema in the region of Bergslagen, we will answer the following research questions: Where were cinemas located in the region? What kind of company or organisation owned and managed the cinema operations? What was the size of the cinemas in terms of seating capacity? Are there co-variations between features attributed to location and features attributed to ownership, considering also seating capacity? Did changes occur over time?

Reflecting on procedures and problems of doing comparative work within the field of new cinema history, Daniel Biltereyst, Thunnis van Oort and Philippe Meers insist that when comparing geographical and /or temporal contexts, it is imperative to consider wider socioeconomic and political traditions and processes in the analysis. ${ }^{8}$ Limiting the scope of comparative analysis to the film industrial context may pose a risk of failing to discover and consider important factors tied to the analysis of a specific historical context. To avoid this risk, our study includes integrated layers of contextual knowledge specific to Sweden and the Bergslagen region while performing the location analysis. Hence, the presentation of our research begins with a recollection of a sociocultural and political understanding of key historical processes with bearing on the cinemas in Bergslagen, followed by an analysis of categories of cinema in Sweden based on ownership and including key historical processes that have had decisive effect on the exhibition sector and its relations. This first part of the study draws largely from secondary sources. The second part of the study presents results from quantitative analysis of a data set of cinemas in Bergslagen. The data set, collated by the authors, includes information on ownership, seating capacity and geographic coordinates of the cinemas. Besides noting shifts in the mentioned properties of the cinemas over time, we map their location and consider demographic features of the region as well as distance between locations of different size. In a concluding discussion, we synthesise the results from the contextual and empirical analysis in a reflection on possible generative mechanisms that could explain variations and persistence of rural cinema. The ambition is not to provide an exhaustive explanatory historical narrative of the persistence, shifts and turns in the cinema exhibition in Sweden. It is rather to provide a detailed account of which cinemas (in terms of ownership) were where, while concentrating on a particular region in Sweden, and to relate some of the features of this data to the broader socio-economic, political and more specific film industrial changes happening in the period studied. 


\section{The region of Bergslagen - localities and population}

The study is concentrated to four counties in central Sweden - of 21 possible - with 53 municipalities, out of 290 municipalities in total in the country. The four counties are Dalarna (also known as Dalecarlia), Värmland, Västmanland and Örebro. Together they cover an area of 60,000 square kilometres that largely overlaps with the old industrial region of Bergslagen. With roughly 1 million inhabitants, the population in Bergslagen adds up to approximately $10 \%$ of the total population in the country. In a European perspective, the population density is very low in Sweden as a whole, with an average of 20 inhabitants per square kilometre. The counties of Bergslagen offer a variation in population density from 53.5 inhabitants per square kilometre in Västmanland, 35.7 in Örebro, 16 in Värmland, to 10.2 in Dalarna. ${ }^{9}$

Regarding settlement structure, the four counties are in some ways representative of the country as a whole.Ineachcounty, as is usual forcounties atlarge, thelargest urbanconcentrationis a medium-sized town withaconcentrationofmorethan60,000residentsthatisalsotheregionaladministrativecentre.Thecountyof Dalarnaishereanexceptionbecauseitstwolargesttowns(BorlängeandFalun)arerelativelysmallandsimilar insize, witharound40,000residentsineachtown.InVärmland,thecapital isKarlstadwith60,000residents; In Västmanland it is Västerås with more than 120,000 residents and in the county of Örebro, the largest town is Örebro and has a population of around 115,000. The remaining urban settlements are predominantly small, withless than5,000inhabitants, whereasthenumberofurban settlementswithmorethan 10,000inhabitants rangefromfive(inVärmland)tonine(inDalarna)in2015. ${ }^{10}$ Thedatabaseassembledfortheanalysisshows 434 localities with one or more cinemas active in at least one point in time between the years 1936 and 2016. The localities vary in size; the smallest ones are locations with less than 200 inhabitants.

\section{Bergslagen as an industrial region}

Bergslagen is an old industrial region. For a long time this region has had by far the most important concentration of iron and steel production in Sweden.Beginning in the seventeenth century, the scale of the operationsgrewsteadily,andtheproductionsitesdevelopedintocommunitieswithstrongsocialhierarchies and a patriarchal system of governance. Although the sites were dispersed throughout the region in socially contained communities, theywere internationally connected.Produce was exported to continental Europe while entrepreneurs, capital, labour and knowledge was to some extent imported. When industrialisation eventually gained momentum in Sweden at large from the 1870s, the existing capacity in Bergslagen to 
produceironandsteelasinputsforconstruction ofengines,railways, andmachinerywasofgreatimportance. Iron ore and steel production in the region became one of the corner stones of the evolving export-oriented Swedish industry.

Nevertheless, the sectorhas been severelyhitbyrecurrent rounds ofrestructuring. Thefirstextensive wave of closures took place during the second half of the nineteenth century. A second round of structural change occurred in the 1920s due to an increase of international competition and a third period of restructuringstartedin themid-1970s.Everyround of restructuringhasled toincreased concentration and specialisation at the level of the plant, and considerable employment problems in many of the small municipalities. ${ }^{11}$

Thelabourmarket in manyof the small towns inBergslagen has been dependant on onelarge employer andthemunicipalitiesareconsequentlyvulnerabletochangeswithinthedominantcompany.Miningandsteel production has also created an image of men's work in the mills and in the mines as defining identity of the region. In the heyday of the mining and steel industry, this image was associated with the prosperity of the region. The image of Bergslagen as based on a strong working class identity and masculine labour was shattered in the 1970swhen theindustrial crisisled to rapid deindustrialisation, highlevels ofunemployment and depopulation of towns in the region. ${ }^{12}$ Up until today, many of the small municipalities in the region struggle with the effects of reduced employment in the manufacturing industry and relatively high levels of out-migration, especially of young adults. ${ }^{13}$

Overthecenturies, thefeatures of theBergslagenregionhas shaped thesocio-economicsettingofthe area, creating a specific set of social relations and institutions. This includes traditional gender contracts, strict social hierarchies, low levels of social mobility and of entrepreneurship, as well as low levels of education. The many industries created a well-organised labour movement in the region, and the Social Democratic partyhashadoneofitsstrongholdsinBergslagen. Somescholars arguethat thesmallindustrial towns, such as the ones in Bergslagen, were prototypes of the development of a specific Swedish model, characterised by a high degree of consensus between social classes in society. This model is known as Folkhemmet (The People’s Home). ${ }^{14}$

\section{Societies, Folkets Hus and cinema}

Bergslagen is particularly interesting for this study because it represents an overall rural area that offers a variation of settlement patterns, and at the same time, it is a condensed and intensified representation of Sweden's industrial rural landscape. This is important for the study of historical 
cinema exhibition because, from a rural perspective, the workers' movement has been influential in the film and exhibition sector in Sweden. Already at the beginning of the twentieth century, local societies across the country belonging to grassroots, civil societies opened their venues to travelling exhibitors. ${ }^{15}$ Venues built and managed by societies organised in the workers' movement, the temperance movement and a smaller number of other kinds of voluntary societies, such as local youth associations and sports clubs, have together created a fine-grained infrastructure of spaces across the country for social gatherings and events, including regular public exhibition of film. Many societies came to open and run cinemas within their own association. Of these spaces, Folkets Hus, i.e. multipurpose venues built by societies tied to the workers' movement, was by far the most common. A literal translation of Folkets Hus would be The People's House. ${ }^{16}$ In the wake of industrial expansion around the turn of the century, Folkets Hus were built in cities, towns as well as in or in-between smaller communities. The initiative came from local labour unions. They formed societies for the sole purpose of raising funds for, building and maintaining a house in which to meet. ${ }^{17}$ Societies and organisations belonging to the temperance movement also ventured into film exhibition and came to dominate in some pockets of rural areas, ${ }^{18}$ yet on a national scale the cinemas run by the temperance movement were not as proliferate as those belonging to the workers' movement were. Because Bergslagen is an old industrial area, we can expect a large presence of Folkets Hus cinemas in the region. Folkets Hus cinemas are presented in more detail below, under the heading 'Society-driven cinemas'.

\section{Cinema exhibition; an overview of industrial conditions over time}

This brief account will highlight two historical ruptures. The first occurred in the late 1940s and early 1950s, following the recognition of the film industry's high profitability and involved state interventions and the attempts of the major film companies to curb competition from associations organised in the civic sector, such as the Folkets Hus and temperance cinemas. The second occurred in the late 1950s and early 1960s as an effect of the introduction of television. The account also describes more gradual historical change beginning with the format of the film programme exhibited in the cinemas. In 1936, the time at which this study starts, the narrative feature was the main attraction in an entertainment package that comprised the international standard commercial cinema 
exhibition format. ${ }^{19}$ This programme format would remain largely intact throughout the period under investigation, though the number of short films, such as commercials, animated comedy, newsreels and actualities, shown before and after the feature, varied over time. With the digitisation of cinema projection in the mid- to late '00s, other formats involving live broadcasts of cultural and sport events were introduced and screened alongside the feature film programme.

Inhibiting profits, the government enforced a ban on raising the price of cinema tickets in 1942 . The restrictionlasteduntil 1948when itbecameuntenableduetoa drasticraise of thetax oncinematicketsales. Film companies protested against the tax raise and a production strike started in the spring of 1951 . The state responded by revising the tax; it was decided that $20 \%$ of the $25 \%$ tax would be reinvested in the industry, andgotothefilmproducers. This system, whichstrengthenedtheverticallyintegrated companies but not theindependent and society/driven cinemas, was in practice until thelate 1950s. It was criticised by publicopinionforencouragingtheproduction of 'cheap,crowd-pleasing,vapidandspeculative'filmsrather than artistically interesting ones. ${ }^{20}$

Toward the end of the 1950s, there was a drastic decrease in cinema attendance; in only seven years, attendance dropped byhalffrom close to 80 million in 1956 to 40 million in $1963 .{ }^{21}$ The single mostimportant explanation to the decline is theadvent of television, ${ }^{22}$ which started regularbroadcasts in 1956 and spread to moreorlessallhouseholdswithinaten-yearperiod. ${ }^{23}$ Thegovernment responded tothecrisis bycomingto an agreement with representatives of the industry in restructuring the tax system and creating a new government body, Svenska Filminstitutet (The Swedish Film Institute). The institute had representatives from both the industry and government on its directory board, and it had as its main task to distribute financial support to the production of 'valuable' Swedish film. ${ }^{24}$ Instead of a general government tax on cinema ticket revenues, $10 \%$ of the gross ticket revenues from cinemas that offered more than five screenings per week went to the new foundation. Important to note is that the vast majority of the cinemas in rural areas did not pay the tax since they rarely exhibited film more than five times a week.

Beginning in 1982, the state provides some (limited) funding for the distribution and exhibition of 'valuable' film, administered through Svenska Filminstitutet. ${ }^{25}$ In the late 1980s, the state monopoly on televisionendedandinstead oftwo(publicservice)channels, multiplesatellitechannelsbecameavailable. ${ }^{26}$ Furthermore, by 1994, 70\% of the households in Sweden had a VHS player connected to the television screen. ${ }^{27}$ Home theatres, portable personal computers and access to film on the Internet have since flourished, ${ }^{28}$ yetcinemaattendanceseemsunaffectedbythelatertechnologicalchanges. Thenegativetrend 
incinemaattendance continued upuntil the 1990s.Attendancestabilisedintheearly 1990 swithbetween 15 and 18 million visits per year. ${ }^{29}$

As mentioned earlier, different kinds of companies and associations owned cinemas in Sweden. In our study, we have identified four categories of ownership. Cinemas could be owned by local grassroots, voluntary societies or (after 1940) by national cinema organisations under the auspices of either the workers' or the temperance movements; they could be owned by a small firm; they could belong to large corporations with a vertically integrated company structure; and finally, we have a rest category of other cinemas. Below follows a presentation of the categories of ownership, with special attention to the society-driven cinemas and in particular Folkets Hus cinemas, which were not only in majority, they were idiosyncratic to Swedish cinema history and, largely due to their socio-political abode, their operative conditions of course changed over time.

\section{Society-driven cinemas}

As mentioned earlier, venues built by societies tied to the workers movement, the temperance movement and a smaller number of other kinds of grassroots organisations, such as local youth and sports clubs, formed an infrastructure of community venues across the country. Many societies opened cinemas within their own association. Of these, as mentioned earlier, Folkets Hus cinema was the most common. Folkets Hus is part of a tradition of oppositional social engagement that started with the revivalist religious movement in the early- to mid-nineteenth century, after which came the temperance movement and, towards the close of the same century, the workers' movement. The three social movements have in common that they were largely composed of people from the working class. ${ }^{30}$ Furthermore, they were a threat to parts of established society, not least for their democratic and socialist impulses in organising large parts of the population, which, up until universal suffrage in 1921, lacked political power. In early twentieth century Sweden, only a few religious denominations besides the Protestant Lutheran State Church were tolerated by law; temperance societies across the country strove to restrict the influence of alcohol and also lobbied for social reform such as women's rights; and the societies tied to the workers' movement shared the values and struggles of the labour unions. Many local societies in all three movements shared the problem of rejection from existing community venues. In order to support their activities, they built their own venues in which to meet. ${ }^{31}$ For the temperance and workers societies, organising activities such as dances and bazaars, offering a hall in the venue to travelling performers not least 
film exhibitors, also to commercial cinemas on longer contracts or even starting a cinema of ones' own, were ways to finance the loans and the maintenance of the houses. ${ }^{32}$

In scarcely populated rural areas, the first-generation of Folkets Hus built between 1900 and 1939 were modelled on the houses of the temperance movement, which in turn were inspired by the venues built by the religious revivalist movement. Typically, local members financed the building of Folkets Hus and they used local skills and material. A common layout of the venue would have a large rectangular hall for meetings and two smaller rooms. In one of the small rooms, there would be a kitchen since coffee was important for meetings in all of the three movements, ${ }^{33}$ and the other room was used for smaller meetings. If the house also had a second story this space would be reserved as living quarters for the caretaker of the house. There would be mobile benches or chairs. Sometimes a stage and a screen. In scarcely populated rural areas, the venues did not change much over the decades. In areas in which the industries and towns expanded in the early to mid-20th century, so did the venues. ${ }^{34}$

In the expanding towns, the second-generation venues built in the 1940s to the 1960s were typically much larger, multifunctional buildings placed in a centrallocation in the town. This wasin partaneffect of a tendency toward centralisation within the organisation of the workers movement. Furthermore, as the workers movement changed from being in opposition to becoming a close ally to the Social Democratic regime (that remained in government from the early 1930s to the mid-1970s), Folkets Hus became part of hegemonic culture and the established community. ${ }^{35}$ A legislation that the government passed in 1942 is clear evidence of the changed social status of Folkets Hus. The new law offered state funding and loans to communityvenues, including thoserun bytheworkers and thetemperancemovement, thusindirectlyalso supporting the society-driven cinemas. At this time, local municipalities could invest in building or reconstructingolder Folkets Hus, changing the functions of thevenue. The newFolkets Hus are oftenlarge, multifunctionalbuildingswithpurpose-specificspacesconstructedforavarietyofactivities:cinema,theatre, meetings, dancing,restaurantsandcafés,music,libraryandevenforadministrativeandpublicfunctionstied to the municipality as well as for commercial banks and local shopkeepers. ${ }^{36}$

Cinema in Folkets Hus could be a local affair owned and run by the Folkets Hus society; this was typically a society initiated by, yet separate from, the local union and created specifically to finance, build, maintain and manage the house with all its activities. Already in the early 1930s, a group of Folkets Hus societies joined forces and created a distribution circuit. Soon thereafter a national organisation of Folkets Hus was established, Folkets Husföreningarnas Centralorganisation. It was renamed Folkets Hus 
Riksorganisation (FHR) a few years later. FHR actively reached out to local societies with advice, technological and other expertise concerning cinema exhibition, and encouraged the cinemas Folkets Hus as well as temperance and other society-driven cinemas - to join their distribution chains. A new company with ties to the workers' movement, Sveriges Folkbiografer, started acquiring cinemas with the purpose of building a national cinema chain. Sveriges Folkbiografer soon merged with FHR. Besides Folkets Hus societies, a number of temperance societies also joined the national and regional distribution chains run by the workers' movement. This happened despite the fact that the temperance movement at around the same time founded a national organisation of their own to support cinema exhibition. Furthermore, in the 1940s, a number of organisations of the workers' movement invested in the film production companies Filmo and Nordisk Tonefilm, thus creating an integrated corporate structure with control over feature film production, distribution and exhibition. ${ }^{37}$

As the workers movement grew and gained political momentum, so did the number of cinemas owned bylocal societies aswell as cinema chains and distribution circuits that operatedunder theaegis of themovement. The mobilisation of cinema bytheworkers' movement in the 1940s was meanstoexpand its (ideological) power. ${ }^{38}$ The fervent activity within the workers movement of organising supportfor and securing film, competence and proper material facilities for cinema exhibition was also a reaction to increased pressure from the commercial cinema sector. The trade organisation of cinema owners, Svenska Biografägareförbundet (SBF), controlled by the major, vertically integrated film companies, set out to curb competition from the non-commercial, society-driven cinema sector in the late 1930s and early 1940s. The SBF decided in 1938 to prohibit the copy of Swedish feature film (including narrative short film) from $35 \mathrm{~mm}$ to $16 \mathrm{~mm}$ film. Furthermore, the industry representatives agreed to regulate the copy of foreign feature film to $16 \mathrm{~mm}$ film. According to the new regulations, only foreign films that had been on the $35 \mathrm{~mm}$ rental market five years or more were allowed to be copied to $16 \mathrm{~mm}$ for national distribution. Making matters worse for society-run cinemas, SBF signed an agreement in 1941 with the organisations for film producers and distributors to regulate the opening of new cinemas. SBF's approval was required to open a new cinema or else the cinema would risk not having access to Swedish film, which was difficult since Swedish-language film was very popular with the audiences. In 1942, SBF introduced more restrictions on film distribution, by stopping all rental of $35 \mathrm{~mm}$ film that was less than two years old and 
by demanding that all cinemas respected the agreed market price for tickets, regardless of where the cinema was located, who owned it or the number of screenings it offered per week. ${ }^{39}$ If the major film companies thwarted the non-commercial, society-driven cinemas' attempts to expand and thrive in the early 1940s, as mentioned earlier, the Social Democratic government indirectly endowed the societydriven cinemas by offering funding opportunities for refashioning and enhancing the venues. ${ }^{40}$

Despite the above mentioned hardships cinema going peaked in Sweden in 1956 with an annual attendance of 10,7visits percapita.With theadventoftelevision,camearapiddeclineinattendance. ${ }^{41}$ Yet the national, non-commercial organisations involved in cinema exhibition remained passive. The production companies owned by the workers' movement failed to produce films that were successful at the box office, and were eventually sold. In the year 1970, FHR finally takes action with the initiative to offer'quality films' on a regularbasis and to a low price. ${ }^{42}$ Again, therewas a period of non-action while the major companies in the commercial exhibition sector sold their single screen cinemas and opened multiplex cinemas in cities and regional urban centres. FHR became FHP, Folkets Hus och Parker, after FHR merged with the national organisation for the workers' recreational parks in the year 2000. The new organisation acquired cinemas in key cities in Sweden, Malmö, Gothenburg, Helsingborg and Stockholm. Furthermore, FHR was quick to recommend Folkets Hus cinemas to take the opportunity to install digital film projectors in their venues when the state offered financial support to do this, a few years later.

\section{Independent cinemas}

The second category is composed of cinemas owned by a private person or a smaller firm. This kind of ownership could involve a single cinema or a chain of cinemas. The latter type of cinema would include travelling companies that travelled on a rotating schedule to a number of small locations. In the course of this study, we have come across a few companies - that were not vertically integrated corporate structures - yet owned and ran stand-alone purpose-built cinemas in towns and sometimes owned more than one cinema. A fair share of private entrepreneurs, however, owned a cinema company that hired space for exhibition in a multipurpose community venue, in turn owned by a local association. We know this from the listings of cinemas in the records of Filmägarnas Kontrollförening, which were presented in order of location and revealed the name of the cinema venues as well as of the cinema owners (see under the heading 'Data and methods'). 


\section{Major company cinemas}

There is a long tradition of vertically integrated film company organisation in Sweden; in December 1919, the two competing film corporations AB Svenska Biografteatern and AB Skandia merged to create Svensk Filmindustri $A B(\mathrm{SF})$. The corporation controlled three film studios, an organisation for distribution that included companies for film import and rental, as well as a chain of 90 cinemas. By the time of 1936, when our study begins, two other companies, AB Europa Film and Sandrew, joined forces to create a second, vertical organisation for film production, distribution and exhibition in Sweden. AB Europa Film and Sandrew continued to expand through merging with or acquiring other companies in the industry and by the end of the decade, they were each vertically integrated corporations. The three companies, Svensk Filmindustri, Europa Film and Sandrew, formed the economic backbone of the Swedish film industry throughout most of the twentieth century. In 1984, Svensk Filmindustri acquired Europa Film. In 2004, Sandrew sold the corporation's cinemas and in 2011, they closed down their office for distribution for theatrical exhibition. ${ }^{43}$ A decade later, SF Bio, affiliated to Svensk Filmindustri, dominated the Swedish cinema exhibition sector, being in control of roughly $80 \%$ of the market. ${ }^{44}$

The cinemas controlled by the major companies operated exclusively in cities and larger towns. In general,thesecinemas offered14ormorescreeningsperweek.In1969,Sandrewinvestigatedthepossibility of reconstructing larger stand-alone cinemas by splitting them up into two or more smaller screening rooms. ${ }^{45}$ Sandrew opened the first multiplex with three screening rooms in $1970 \mathrm{in}$ Stockholm and within a decade had 24 multiplexes and 6 single cinemas in 22 cities and towns. ${ }^{46}$ In the early 1980 s, Svensk Filmindustri caught on and invested in larger multiplex cinemas, closing many of their single screen venues. ${ }^{47}$

\section{Other cinemas}

The fourth category of cinema ownership include military cinemas that exhibited film at the garrisons during the time when the country was in a state of military mobilisation during and following World War II. Screenings at the garrison cinemas were public yet we do not known whether the cinemas indeed attracted an audience beyond military personnel. Cinemas owned and run by municipalities are also included in this category. Specific to municipality-driven cinemas is the commercial constraint on their operations - municipal cinemas may not compete with commercial cinemas. 


\section{Data and methods}

\section{Data sources and the long-historical approach}

The empirical data covers a, for film history, exceptionally long period, from 1936 to 2016, i.e. 80 years. The study builds on data of active cinemas in Bergslagen for the years 1936, 1946, 1956, 1966, 1978, 1986, 1996, 2006 and 2016, produced by Filmägarnas kontrollförening (FKF) (also known as Filmägarnas kontrollbyrå). Cinema lists for the earlier decades of the twentieth century are only available at random years. Using approximate ten-year intervals, starting with 1936, provided regularity in the chronology of the study. Please note that the regularity is not exact; there are no records of cinemas active in 1976 but data was available for 1978. There are also variations in the data as to whether the data refers to the beginning or the end of the year recorded. The long period covered by the study offers the opportunity to follow patterns of cinema exhibition through a series of politico-economic structural changes as well as through changes more closely tied to the conditions that frame and define the practice of cinema going.

The empirical data in the cinema lists, including name of cinema, location, seating capacity and category of ownership, on which the analysis is based, is packaged and published in different ways for different years, yet all the data comes from the same original source, FKF. The organisation represents the interests of film producers and distributors in Sweden, and since 1932, the bureau keeps records of cinemas inSwedenthatofferpublicscreeningsforcalculatingrevenuesfromfilmrentals.FKFbasesitscalculationson ticket price and ticket sales, in relation to the seating capacity of the cinema. Data for the years 1936, 19461947 and 1956, have been published by SBF. The Swedish Film Institute library has in its archive a manual card catalogue originally used by the bureau. The cards offer a manual system of pencil recordings of the information required about active cinemas for the years 1934 to 1971. We retrieved from it information of Bergslagen's operativecinemasin 1966; there are noready-madelistings of cinemas of the $1960 \mathrm{~s} .{ }^{48}$ Finally, FKF gave us access to the bureau's archive of printed computer listings starting from the year 1978. We retrieved printed data lists for 1978, 1986 and 1996. For 2006 and 2016, FKF sent us records data in digital form.

Information on population size in the localities in the Bergslagen region was retrieved from the 1950 population census (Folkräkningen 1950), and from Statistics Sweden for population figures for 2015. Though it is likely the population size of the localities varied in the years covered by the study, we have kept the 1950 population size throughout the whole period. The reason is that, although 
population figures change, the vast majority of the localities remain within the same size group over time. The maps in figure 4 and the calculation of nearest neighbour distances between localities with at least one cinema (see below and figure 5) is mainly based on spatial coordinates provided by Statistics Sweden. For a small number of localities (approx. 20 localities) we used an interactive on-line map (Hitta.se) to gather coordinates. As mentioned earlier, we identified in total 434 localities with at least one cinema in at least one point in time. In this article, we use the term locality (in Swedish, tätort) as synonymous to a settlement or a population agglomeration.

\section{Methods}

Maps and descriptive statistics are used to present the spatial distribution of cinemas, and cinema seats, in the region by ownership categories, and locality size. A specific measure of the spatial configuration of cinemas is also used. The Nearest Neighbour-Index (NNI) measures the spatial arrangement of locations (i.e. localities with at least one cinema) on a scale from 'highly clustered' to 'highly dispersed'. ${ }^{49}$ The index is a comparison of the observed spatial pattern of locations (the average of nearest neighbour in kilometres) and a theoretical random distribution (the density of localities per km2), using the following formula:

$N N I=\frac{D}{0.5 \sqrt{a} / n}$

In the formula, $\mathrm{D}=$ average distance to nearest neighbour in $\mathrm{km}, \mathrm{a}=$ area of the region in $\mathrm{km}^{2}$ and $\mathrm{n}=$ number of localities.

The value of NNI ranges from a theoretical zero to a maximal value of 2.15 when the pattern of localities spread evenlyina regular pattern.Values close to 1 representa more random pattern. The purpose of using NNI is to make it easier to judge the spatial configuration, or spatial arrangement, of localities irrespective of the general decrease of cinemas over time. Thus, we will be able to see if the distribution of cinemas in space remains even though the number of cinemas decreases over time.

\section{Cinema location in the Bergslagen region}

The first ten-year period in the dataset, from 1936 to 1946, show a remarkable increase in both cinemas and cinema seats in the region. In relative terms, the number of cinemas and seats increased 
by $47 \%$ and $42 \%$ respectively. Both the number of cinemas and cinema seats had its peak in 1946 and 1956. Ten years later, in 1966, the first real drop in cinema exhibition occurred, reducing the number of cinemas by $31 \%$ and the number of seats by $28 \%$. The decrease continues after that more steadily until 2016. By this time, more than $75 \%$ of the cinemas and $83 \%$ of the seats have disappeared since 1956. The cinema venues have also become smaller over time. The average number of seats per cinema decreases after 1978. Figure 1 thus depicts the story of the rise and decline of cinema, during the latter half of the $20^{\text {th }}$ and the early twenty-first century. The pattern revealed in figure 1 is overall similar to the changes in the country as a whole. ${ }^{50}$ It is interesting to note that the reduction in cinemas and cinema seats does not coincide with the industrial decline in the Bergslagen region. The decrease in number of cinemas obviously precedes the loss of employment opportunities, which started in the mid-1970s. In fact, manufacturing employment (in absolute numbers) was at its highest level in the country, as well as in the Bergslagen region, around 1965 to $1970 .{ }^{51}$ Rather, the decline neatly coincides with the advent of television, though it would be crude to conclude that television andhometheatreexhibitionalternativesalonesufficestoexplaincinemas continuedrecessionthroughout the period.

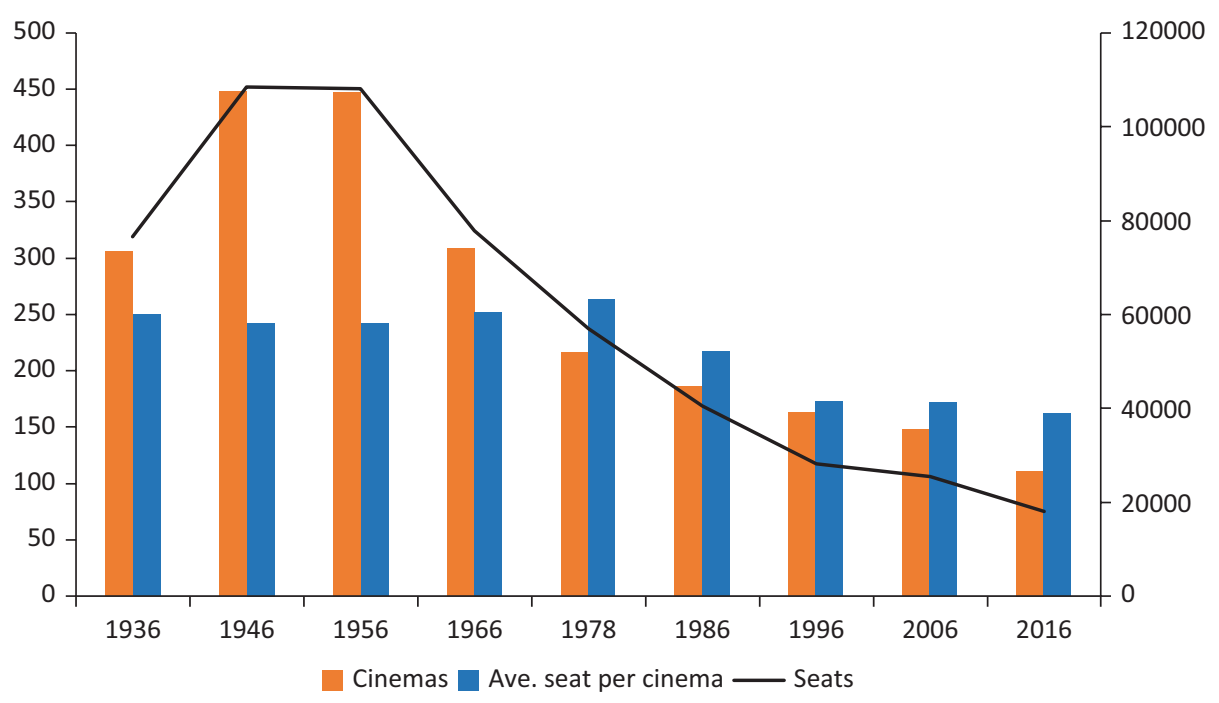

Figure 1. Total number of cinemas, cinema seats (right hand scale) and average seat per cinema 1936-2016 in the four selected counties (Värmland, Örebro, Västmanland, Dalarna). Source: Filmägarnas kontrollförening. 


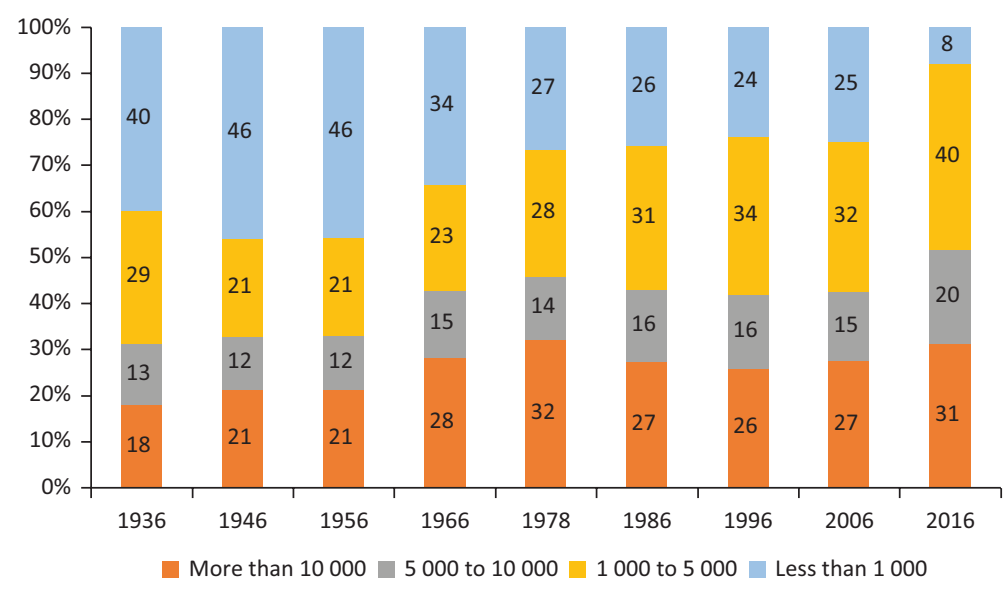

Figure 2. Share of cinema seats in four locality size groups, 1936-2016. Source: Filmägarnas kontrollförening and Folkräkningen 1950.

Figure 2 shows the relative share of cinema seats in localities of different population sizes, from 1936 to 2016. During this period, cinema seats are redistributed in favour of the larger localities and towns. Localities with more than 10,000 inhabitants increase their share from 18 to $31 \%$ over the period, whereas the smallest settlements (less than 1,000 inhabitants) share of total seats decreases from almost $46 \%$ in 1946 , to $8 \%$ in 2016 . The smallest localities have lost the majority of their seats to localities with between 1,000 and 10,000 inhabitants. In 2016, more than $60 \%$ of all seats are in localities of this size.

In Table 1, we introduce the four different ownership categories in the analysis. Over time, a few striking shifts can be noted. In the mid-1930s, independent cinema-owners dominated, both in terms of number of cinemas and cinema seats, but they have since lost ground. Cinemas owned by societies, on the other hand, show a steady increase. Societies owned every third cinema in the region in 1936. Thirty years later,theycontrolled roughlytwothirds ofall cinemas.As related earlier in thearticle,society-drivenandin particular Folkets Hus cinemas, acknowledged the economic and political benefits of cinema operations in the early1940s, and organised national organisations to actively encourage and support cinema within the movements. Cinema had become an integrated part of Folkets Hus in localities of any size. After 1966, the number of society-driven cinemas have decreased, yet the category still upholds 36\% of cinemas in 2016. Major cinema chains started out on a small scale in the 1930s, and have only recently taken the lead 


\begin{tabular}{|c|c|c|c|c|c|c|c|c|}
\hline \multirow[t]{2}{*}{ Year } & \multicolumn{2}{|c|}{ Societies } & \multicolumn{2}{|c|}{ Independent } & \multicolumn{2}{|c|}{ Major } & \multicolumn{2}{|c|}{ Other } \\
\hline & Cinemas & Seats & Cinemas & Seats & Cinemas & Seats & Cinemas & Seats \\
\hline 1936 & 31.4 & 35.6 & 64.1 & 56.6 & 4.2 & 7.7 & 0.3 & 0.2 \\
\hline 1946 & 32.8 & 35.6 & 60.0 & 50.9 & 6.3 & 11.4 & 0.9 & 2.1 \\
\hline 1956 & 51.0 & 51.2 & 40.5 & 33.9 & 6.5 & 11.9 & 2.0 & 3.0 \\
\hline 1966 & 66.0 & 58.7 & 21.7 & 19.9 & 11.3 & 20.7 & 1.0 & 0.7 \\
\hline 1978 & 60.2 & 58.0 & 23.1 & 19.6 & 13.4 & 19.3 & 3.2 & 3.1 \\
\hline 1986 & 63.4 & 66.6 & 16.1 & 14.1 & 17.2 & 16.2 & 3.2 & 3.1 \\
\hline 1996 & 47.2 & 58.3 & 20.9 & 21.2 & 27.6 & 17.3 & 4.3 & 3.3 \\
\hline 2006 & 48.6 & 56.4 & 23.6 & 25.4 & 23.6 & 15.1 & 4.1 & 3.2 \\
\hline 2016 & 36.0 & 49.3 & 20.7 & 22.3 & 37.8 & 23.3 & 5.4 & 5.0 \\
\hline
\end{tabular}

Table 1. Ownership categories and their share of cinemas and cinema seats in the region 1936-2016. Source: Filmägarnas kontrollförening.

quantitatively speaking, controlling more than 38\% of the cinemas in 2016. Military, and later on municipality-owned cinemas (in the owner category Other) have always been a small residual, but throughout the period their share has increased, reaching 5,4\% of cinemas and $5 \%$ of the total number of cinema seats in 2016.

We may also note that the society-controlled cinemas are comparatively large venues, in particular compared to the major chains in the latter part of the period. For instance, in 2016, society-owned cinemas on average had $49 \%$ of the cinema seats, whereas the corresponding figure for major cinema owners was 23\%. This is an effect of the second-generation uplift of the Folkets Hus venues in the 1950s and 1960s, mentioned above.

Figure 3 clearly indicates a relationship between ownership category and settlement size groups. In the first decade recorded here, independent cinema owners show a strong presence in all size groups, to 

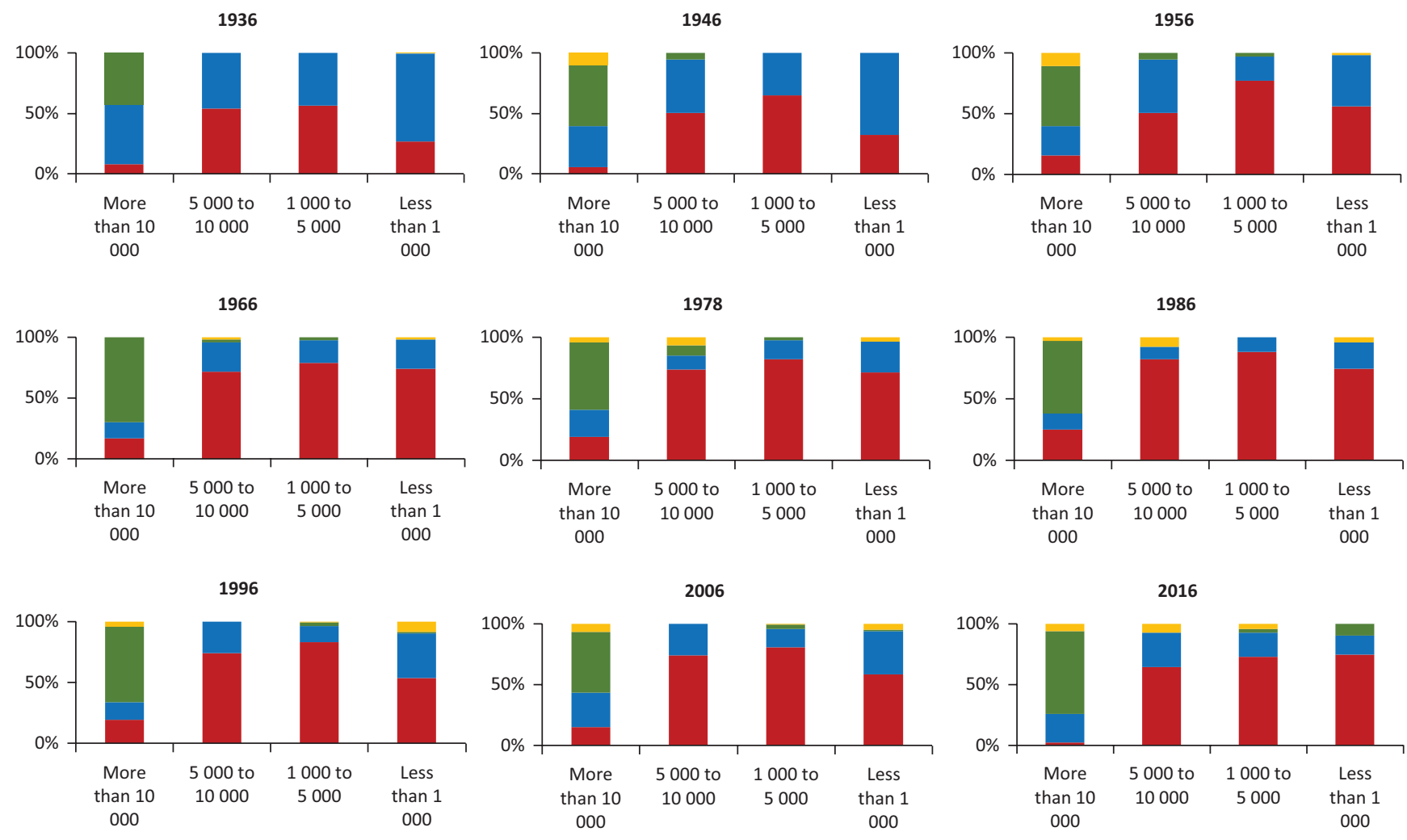

Figure 3. The distribution of cinema seats by ownership categories and locality size groups 1936-2016. Red=Societies, Blue=Independents, Green=Major, Yellow=Other. Source: Filmägarnas kontrollförening and Folkräkningen 1950.

fade as the decades proceed. Majors have a strong connection to the larger towns, and in particular to the regionalcentres of Karlstad,Örebro,Västerås andFalun.Todaytheydominatein thelargeragglomerations. Fromthe1940s and1950s andonwards, civilsociety-driven cinemashavecometodominateinall categories of localities, except in towns with more than 10,000 inhabitants.

Displayed in the maps in figure 4, showing the number of cinemas by owner category in 1956 and 2016, is an illustration of the massive reduction of the number of cinemas during this frame of time. To some degree, the location pattern follows the distribution of the population, with a concentration to the south of the region where the main cities are located. A reduction of cinemas situated near the larger cities is obvious. We can also note that the number of localities with independent cinemas is reduced, and the civil societies dominate cinema ownership in the smaller localities in 2016. Looking at the map of 1956, we find a very fine-grained distribution of localities with one cinema or more. It is also easy to recognise the importance of the society-driven cinemas to 

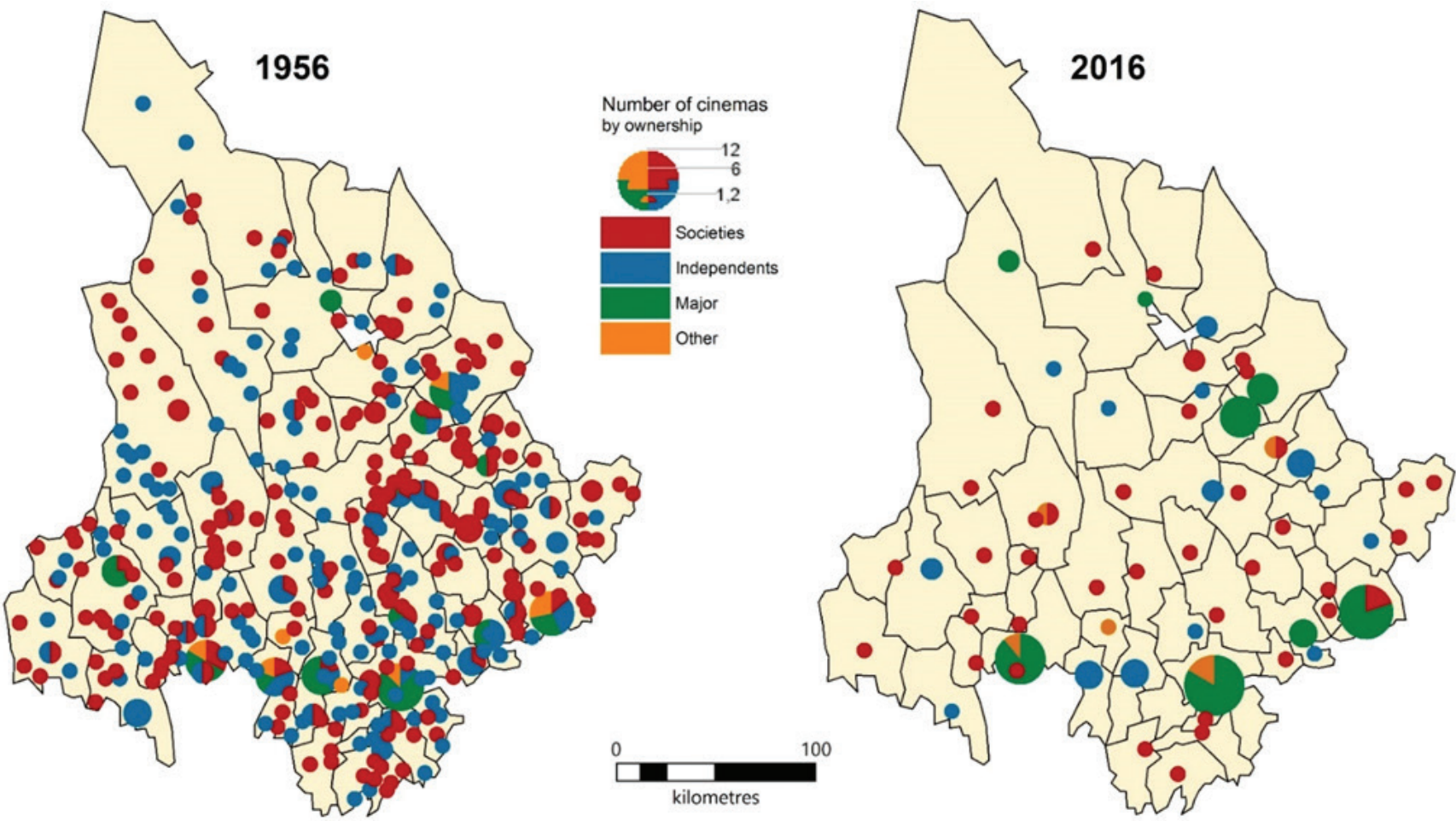

Figure 4. The location of cinemas by ownership 1956 and 2016. Source: Filmägarnas kontrollförening.

this highly scattered pattern. The map of 2016 represents a much more diluted pattern of cinemas. Comparing the two maps, the first impression is that a concentration process has taken place, shifting the centre of gravity to the larger cities in the south. The question arises whether this means that the spatial distribution also became more clustered. To be able to answer this question we need to turn to the Nearest Neighbour Index (NNI). As mentioned earlier, the purpose of using NNI is to make a better judgement of changes in the spatial configuration of localities with cinemas, independent of the overall decrease in the number of cinemas.

Figure 5 displays the number of localities with a cinema for every decade in the period of the study. Three related measures are calculated: 1 ) the number of cinemas per square kilometre (blue staple), 2) the average distancebetweeneachlocalitywith a cinema and its closestneighbour(orange staple), and finally3) theNearest Neighbour Indexforeachyear(line,righthand scale). The number of cinemasincrease from 1936 upuntil1956,and thenfallssteadilyuntil2016.Thischangeis aninversemirrorofthemeasure distancetothe closestneighbour',leading to a slight dropbetween 1936 and 1956, and a weakyetsteadyincrease thereafter. 


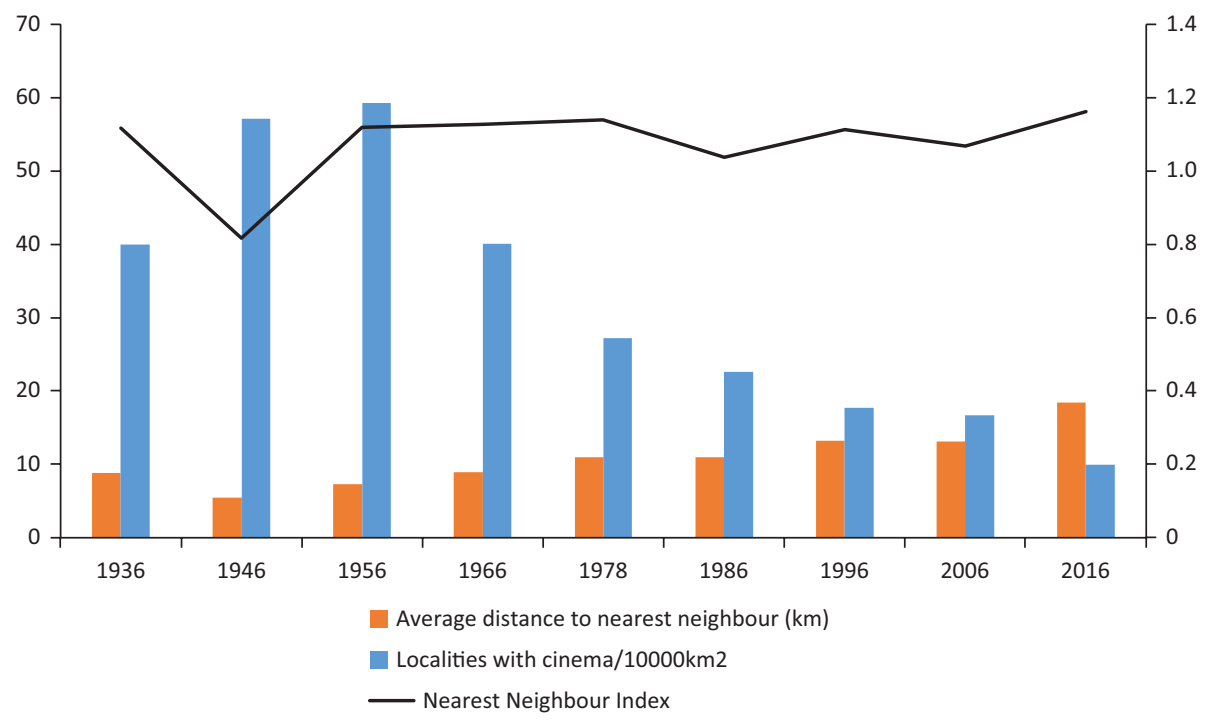

Figure 5. Changes in the spatial configuration of cinemas in the four counties 1936-2016. Density of cinemas, average distance between cinemas and Nearest Neighbour Index. Source: Filmägarnas kontrollbyrå.

Since the NNI expresses the ratio between these two measures, the outcome is dependent on how much each measure changes over time.

As mentioned earlier, the NNI varies between a theoretical zero, and up to 2.15. Values close to zero indicate a clustered location pattern, and values well above 1 indicate a spatially more evenly, or regularly, distributed pattern. Values close to 1 represent a more randomly distributed pattern. From figure 5 we may thus conclude that, measured in this way, the location pattern of cinemas does not become more clustered over time. The NNI does drop to 0,8 in 1946, but thereafter it oscillates around 1,1 the following years. Between 1986 and 2016, thereis actually a slight increasein theindex.If we disregard the modestincreasein the NNI between 1986 and 2016, it is reasonable to conclude that the location pattern of cinemas in the studied region does not show signs of clustering over time. Looking back at the maps in figure 4, we may also conclude that the scattered pattern of cinemas is to a large degree related to society-ownership of cinemas.

There is, however, one problem with the Nearest Neighbour Index that we have not been able to deal with in the calculations; in the smaller localities there is normally only one cinema, whereas in the larger cities we often find more than one cinema. This means that the inhabitants in the larger agglomerations have a choice of several screens to choose between. In Table 2, we present an attempt to 


\begin{tabular}{|c|c|c|c|c|c|}
\hline $\begin{array}{l}\text { Owner } \\
\text { category }\end{array}$ & $\begin{array}{l}\text { No of } \\
\text { cinemas }\end{array}$ & $\begin{array}{l}\text { No of } \\
\text { seats }\end{array}$ & $\begin{array}{l}\text { Population } 2015 \text { in } \\
\text { localities with cinema }\end{array}$ & $\begin{array}{l}\text { Inh. per } \\
\text { cinema }\end{array}$ & $\begin{array}{c}\text { Inh. per } \\
\text { seat }\end{array}$ \\
\hline Society & 40 & 8881 & 295971 & 7399 & 33 \\
\hline Independents & 23 & 4024 & 142585 & 6199 & 35 \\
\hline Major & 42 & 4201 & 405684 & 9659 & 97 \\
\hline
\end{tabular}

Table 2. Inhabitants per cinema and per cinema seat 2015/16 by owner category. Source: Filmägarnas kontrollförening and Statistics Sweden.

address this problem, at least partially.Here, the accessibility of cinemas and cinema seats is measured in relation tothenumber ofinhabitants (in 2015) per cinemaand cinema seats inlocalitieswitha cinema, for three of the four ownership categories. The table builds on the assumption that there is only one type of ownership categoryin each locality. This is a reduction of reality; our research does show a small degree of variation in ownership in the larger cities (municipality-run cinemas in Karlstad and Örebro, a society-driven cinema in Västerås, see the map for 2016 in figure 4). In Table 2, these cinemas are excluded from the analysis. Another problem is the short distances between some of the localities. In other words, the calculation does not take into consideration actual market areas for each individual cinema.

Acknowledging these shortcomings, the calculations in Table 2 nevertheless indicate that the population basis for both the society-driven and independent cinemas is lower than for the major chains. The companies running the major chains concentrate their cinemas in towns with larger populations which fits their commercial goals and operations better. The difference is even more pronounced when it comes to the number of cinema seats. To a degree, the latter is explained by the smaller size of venues in the larger cities dominated by major companies with multiplex cinemas versus the larger theatres in smaller localities dominated by multi-purpose venues driven by societies or independent cinema companies.

Summing up the empirical investigation, we can conclude that the number of cinemas in the region has droppedimmensely from themid-1950s and until today. Consequently, the cinemalandscape is clearly less dense than it was in the 1940s and 1950s. Yet, the spatial distribution of cinemas has continued to be fairly scattered. We have also been able to show that the main agent behind this scattered pattern, both 
historically and moving toward the present day, is the grassroots, voluntary societies that have persisted in keeping cinemas in operation in the region of Bergslagen.

\section{Concluding discussion}

This study has as an underlying premise the unbalanced privileging of metropolitan cinemas in standard accounts that survey cinema history. A small number of vertically integrated major film companies controlled the city cinema market, which included the most profitable cinemas. These cinemas figure also in this research. However, by featuring cinema exhibition in the rural and (post) industrial region of Bergslagen in Sweden rather than Stockholm, a city or larger town, our study brings to the fore and provides a detailed account of the existence of cinemas owned and run by other kinds of companies, organisations and associations. It reveals that the majority of cinemas and cinema seats in the region are in fact, owned and run by these Other companies, organisations and associations. Thus, through implicit comparison, our study ties in with ongoing historical research about cinema culture and exhibition that has disclosed varying conditions for cinema going, not least in rural communities and in times of urbanisation. Judith Thissen makes this point by calling attention to, 'the diversity of dispositifs' in which audiences encountered cinema in villages, hamlets and in small towns in the Netherlands, Germany and France in the 1920s to the 1960s. ${ }^{52}$ In the multifunctional venues of general public buildings and hotels, audiences experienced cinema alongside community-centred and commercial activities. A public bath and a fire brigade were tenants in the public building in the town Saint-Laurent-du-Medoc and it also housed 'balls, parties and dances, performances by (amateur) theatre groups, singing clubs and local bands, gymnastics, lectures and political meetings.' Cinema existed alongside not-for-profit, family-oriented events 'with firm roots in the social and cultural life of the community as well as in grass-roots voluntary organisations. ${ }^{53}$

In this contribution to a more nuanced understanding of the conditions and variations of historical cinema exhibition in Sweden, the study relies on a series of comparisons across temporal and geographic entities. We have examined relations between spatial features of localities (including population density and distance to other locations), ownership and size of cinemas, and changes of these parameters over a period of 80 years. The results underline the importance of grass roots, voluntary society involvement in cinema exhibition in multipurpose venues invillages and towns of varying size, throughout the twentieth century.Ouranalysissuggeststhat thewidespreadassociationalcultureinSwedenthatevolvedintandem 
with as well as in response to processes of modernity, ${ }^{54}$ and its early dependency on multipurpose venues, contributed tothecountry's multitudinous cinemas.Beginningintheearly1940s, governmentbenefaction of community venues and the rise of national organisations that encouraged and in different ways motivated grass roots, society cinemas, led to a decrease in independent company ownership of cinema. Forlocations outside of metropolitan areas, this process of mobilisinglocal societyinvolvement in cinema fosteredamajorityculture ofnot-for-profitcinema exhibition thatwasdependentonassociationalculture. This could explain the persistence of cinemasinrural areas and small towns evenin theage of the multiplex when the option of going to a village cinema all but disappeared in other European countries. ${ }^{55}$ We can concludethat thestructureandtraditionofmultipurposecommunityvenuessustainedbylocalcommunity involvement - albeit since the 1960s aided by the exemption of state tax for cinemas that had five or less screenings a week - has contributed to the persistence of a surprisingly evenly distributed and decentralised geographic pattern of cinema exhibition up until this day. The results are supported by a recentreportfromTheSwedishAgencyforCulturalPolicyAnalysisinvestigatingtheaccessibilityofcinemas in Sweden, based on distance. ${ }^{56}$ The report states that in 2016, 90 percent of the adult population had less than a 15-minute car ride to a cinema, from their home, while close to half of the adult population lived within 3 kilometres of a cinema. These are astonishing figures considering the country's low population density.

Looking ahead,thereis reason forconcern.As politicalscientistErikAmnånotes, civilsocietyrelies on voluntary social work and Scandinavian civil society has been unique due to its large number of members that have also been volunteers. However, in the past few decades in Sweden, while volunteers have increased in numbers, membership in societies has decreased. This has the effect that "more volunteers are detached from inner associational democratic life. ${ }^{57}$ Amnå describes the process thus: 'Voluntary social activities on [sic] the Scandinavian model of self-organised, member-based, nonprofessional associations of non-paid volunteers have left room for the service-oriented, outcomeoriented organisations with hired professionals. ${ }^{58}$ In the year 2000, FHR merged with its sister organisation, Folkparkernas Centralorganisation, which served the amusement parks owned by the workers' movement. In 2019, the new National Association Folkets Hus and Parker (FHP) has 500 member organisations, among which are 140 Folkets Hus cinemas. They benefit from the services offered by the two companies owned by FHP, Folkparkernas Programbolag, involved in the distribution of digital meetings, events and artists, and Framtidens mötesplats, engaged in cinema development. ${ }^{59}$ The temperance movement has also strengthened its central, 'mother' organisation 
and has expanded its scope of (largely cultural and educational) services. In 2019, Våra Gårdar includes 600 community venues and around 50 cinemas. ${ }^{60}$ The question is if this, in Scandinavian terms relatively new, kind of paid, service-oriented model for society-driven cinema and other cultural events, is sustainable.

The question is pertinent considering the total restructuring of the relations between state and film industryinSwedenthat thegovernment recentlyimplemented.As of January1,2017, the stateis solefinancer of the Swedish Film Institute. Its mission, as defined in the Film Bill and in the annual document of grant appropriations from the Ministry of Culture is, 'to support the production of new films, the distribution and screeningofvaluablefilms, topreserveand promoteSweden'sfilmheritageandtorepresentSwedishfilmatan internationallevel. ${ }^{61}$ Tosecurefinancingforthis, thestate(again)enforceda25\%taxoncinematicketrevenues, including also the smaller cinemas that offer less than six screenings per week, which have (since 1963) been exempted from this kind of state tax. ${ }^{62}$ Obviously, this is a hard blow on small cinemas, especially in rural locations with a small population.

Thelongitudinalcomparisons of changesinrelationsbetweenspatialfeatures oflocalities,ownership and size of cinemas in the Bergslagen region has underlined the importance of local societies, and in particular the workers' movements, to the persistent existence and scattered patterns of cinema outside of metropolitanareas.Inordertounderstand theeconomics andcultureofcinemainnonmetropolitanareasof Sweden, which has not been properlyaddressed in this article,furtherresearchinvolving film programming strategies as well as the ethnographic study of audiences would be necessary.

\section{Notes}

1 Richard Maltby, Melvyn Stokes and Robert C. Allen, eds. Going to the Movies: Hollywood and the Social Experience of the Cinema (Reed Hall: University of Exeter Press, 2007); Karina Aveyard and Albert Moran, eds. Watching Films: New Perspectives on Movie-going, Exhibition and Reception (Bristol: Intellect, 2013); Karina Aveyard, Lure of the Big Screen: Cinema in Rural Australia and the United Kingdom (Bristol, UK: Intellect, 2015), Daniël Biltereyst and Daniela Treveri Gennari, eds. Moralizing Cinema: Film, Catholicism and Power (New York: Routledge, Taylor \& Francis Group, 2015); Judith Thissen and Clemens Zimmermann, eds. Cinema beyond the City: Small-Town and Rural Film Culture in Europe (London: British Film Institute, 2016); Daniela Treveri Gennari, Danielle Hipkins and Catherine O’Rawe, eds. Rural Cinema Exhibition and Audiences in a Global Context (Cham, Switzerland: Palgrave Macmillan, 2018). 
2 Leif Furhammar, Filmen i Sverige: en historia i tio kapitel och en fortsättning [3rd ed.] (Stockholm: Dialogos, Svenska Filminstitutet, 2003), 135.

3 This point has been made by other scholars, initially and most famously by Robert Allen and shortly thereafter by Kathryn Fuller-Seeley. They have suggested that a focus on metropolitan exhibition has, to quote Karina Aveyard, 'obscured the significance of the geographic dimensions of cinema-going, which in turn has given rise to a reductionist narrative that has seen the cinematic experience linked primarily with the rise of the twentieth-century metropolitan modernity to the exclusion of other formations.' Aveyard, Lure of the Big Screen, 9; Robert Allen, "Relocating American Film History: The 'Problem' of the Empirical," Cultural Studies 20, no. 1 (2006): 64-65; Kathryn Fuller-Seeley and George Potamianos, "Introduction: Researching and Writing the History of Local Movie-Going," in Hollywood in the Neighborhood: Historical Case Studies of Local Moviegoing, ed. Kathryn Fuller-Seeley (Berkeley: University of California Press, 2008).

Carina Sjöholm, Gå på bio: rum för drömmar i folkhemmets Sverige [dissertation] (Eslöv: B. Östlings bokförl. Symposion, 2003); Anna Cedergren, Håkan Berglund-Lake and Mattias Bäckström, eds., Biografliv (Sundsvall: Stockviks Folkets hus, 2005); Åsa Jernudd, “Cinema Memory: National Identity as Expressed by Swedish Elders in an Oral History Project," Northern Lights: Film \& Media Studies Yearbook 11, no. 1 (2013): 109-122; Åsa Jernudd, "Cinema, Memory and Place-related Identities: Remembering Cinema-going in the Post-industrial Town of Fagersta in Bergslagen," in Regional Aesthetics: Locating Swedish Media, eds. Mats Jönsson, Olof Hedling and Erik Hedling (Stockholm: Kungliga biblioteket, 2010), 169-189.

5 Cedergren et al, eds. Biografliv; Åsa Jernudd and Mats Lundmark, "Cinemagoing in Sweden in the 1940s: Civil Society Organisations and the Expansion of Rural Film Exhibition," in Cinema beyond the City, eds. Thissen et al., $67-86$.

6 Åsa Jernudd, “Spaces of Early Film Exhibition in Sweden, 1897-1911," in Cinema Audiences and Modernity: New Perspectives on European Cinema History, eds. Daniël Biltereyst, Richard Maltby and Philippe Meers, (London: Routledge, 2012); Furhammar, Filmen I Sverige; Mattias Bäckström, ”Striden om biosalongerna: folkbiografer eller privata biografer på Folkets hus,” Arbetarhistoria 29, no. 4 (2005): 25-30.

7 Mattias Bäckström, “Ljudbilder och biomörker: Om brytpunkter i biografernas historia i Medelpad och Ångermanland," in Biografliv, eds. Cedergren et al., 106-155; cf. Jernudd et al. "Cinemagoing in Sweden".

8 Daniël Biltereyst, Thunnis van Oort and Philippe Meers, "Comparing Historical Cinema Cultures: Reflections on New Cinema History and Comparison with a Cross-national Case Study on Antwerp and Rotterdam," in The Routledge Companion to New Cinema History, eds. Daniël Biltereyst, Richard Maltby and Philippe Meers (London Routledge, Taylor and Francis Group, 2019), 96-111. 
9 "Population in the country, counties and municipalities on 30 June, 2019 and population change in AprilJune 2019,” SCB.se, accessed September 17, 2019. https://www.scb.se/en/finding-statistics/statistics-bysubject-area/population/population-composition/population-statistics/pong/tables-and-graphs/ quarterly-population-statistics--municipalities-counties-and-the-whole-country/quarter-2-2019-/

10 ”Tätorter2015;befolkning2010-2018,landareal,andelsomöverlappasavfritidshusområden,"SCB.se,accessed September 17, 2019. https://www.scb.se/MI0810.

11 Jan-Erik Pettersson, Från kris till kris: den svenska stålindustrins omvandling under 1920- och 1970-talen (Stockholm: Institutet för ekonomisk historisk forskning vid Handelshögskolan, 1988); Mats Lundmark, Mona Hedfeldt and Max Jakobsson, Bergslagen: en industriregion i upplösning? (Stockholm: Riksantikvarieämbetet, 2016).

12 SuneBergerandMatsLundmark,"FörändringavarbetslivochlivsformeriBergslagen,”(Workingreport,Uppsala University, 1989).

13 Lundmark et al., Bergslagen: en industriregion.

14 Maths Isacson, ”Bruket och folkhemmet," Häften för kritiska studier 24, no. 2 (1991), 16-24.

15 Rune Waldekranz, "Levande bilder: de första biograferna” (Utgiven med anledning av Sveriges biografägareförbunds 40-årsjubileum 1955, Förb., 1955); Jernudd,"Spaces of Early Film Exhibition in Sweden.”

16 The term was a translation from the French Maison du Peuple, adopted from the Belgian workers movement in the 1890s. Margareta Ståhl, Möten och människor i Folkets hus och Folkets park (Stockholm: Atlas, 2005), 20.

17 Torbjörn Almqvist, Hjördis Johansson and Lena Simonsson, Vad folket byggde: ett utkast till folkrörelsernas byggnadshistoria (Stockholm: Sveriges arkitekturmuseum, 1976), 16-17.

18 Jernudd et al. "Cinemagoing in Sweden."

19 Douglas Gomery, Shared Pleasures: A History of Movie Presentation in the United States (Madison, Wis., Univ. of Wisconsin Press, 1992).

20 Furhammar, Filmen i Sverige, 206-207.

21 Vesterlund, “Den svenska modellen,” 214.

22 '....all scientific studies of the course of events, geographically and temporally, all statistics of the overall effects andalleverydayobservations of local events, wereunambiguous. Nothing couldhidetheobviousfact that TVwas the direct and fully sufficient cause of the drastic drop in cinema audience attendance and the cinema crisis.' Transl. by article author. Furhammar, Filmen i Sverige, 249.

23 Karl-Hugo Wirén, Kampen om TV: svensk TV-politik 1946-66 (Malmö: Gidlunds, 1986), 12. 
24 The term 'worthwhile film' is used by the Swedish Film Institute in the presentation of its remit on the web. See https://www.filminstitutet.se/en/about-us/swedish-film-institute/mission-and-organisation/

25 Furhammar, Filmen i Sverige, 352.

26 Lennart Weibull, "Fyra decennier i Mediesverige" in MedieSverige 2014. Statistik och analys, eds. Ulla Carlsson and Ulrika Facht (Göteborg: NORDICOM-Sverige, 2014), 14.

27 Magnus Anshelm, "Video" in Medie-Sverige: statistik och analys. 1/1995, eds. Ulla Carlsson and Magnus Anshelm, (Göteborg: NORDICOM-Sverige, 1995).

28 Weibull, "Fyra decennier i MedieSverige," 19.

29 Ds 2015:31, 38.

30 Sven Lundkvist, Politik, nykterhet och reformer: en studie i folkrörelsernas politiska verksamhet 1900-1920 (Uppsala: Uppsala Univ., 1974).

31 Karin Lindvall and Christian Richette, "Folkrörelser och folkrörelsemiljöer," Från bergslag och bondebygd 33, (1979), 111-226, 139-140, 186, 209.

32 Jernudd et al. "Cinemagoing in Sweden"; Per Vesterlund, "Den svenska modellen: arbetarrörelsen, staten och filmen," in Medier \& politik: om arbetarrörelsens mediestrategier under 1900-talet, eds. Mats Jönsson and Pelle Snickars (Stockholm: Statens ljud och bildarkiv, 2007), 207-246.

33 The importance of local ownership of venues, and a kitchen, to the success of the three movements in social and educational terms - in fostering community and democracy - has been stressed by Bengt Göransson, prominent Social Democratic politician and honorary doctor at Gothenburg University, with a lifelong private as well as professional engagement in both the temperance and the workers movements. Bengt Göransson, “Ett nästintill oidentifierbart forskningsområde," in Civilsamhället: Några forskningsfrågor, ed. Erik Amnå (Stockholm: Riksbankens jubileumsfond i samarbete med Gidlund, 2005), 37-44.

34 Almqvist et al. Vad folket byggde; Lindvall et al. "Folkrörelser och folkrörelsemiljöer," 210-214.

35 Michele Micheletti, Det civila samhället och staten: medborgarsammanslutningarnas roll i svensk politik (Stockholm: Fritze, 1994), 69.

36 Lindvall et al. "Folkrörelser och folkrörelsemiljöer," 214-226.

37 Vesterlund, ”Den svenska modellen.”

38 Ibid., 233.

39 Bäckström, "Striden om biosalongerna"; Jan Olsson, Svensk spelfilm under andra världskriget (Lund: LiberLäromedel. Dissertation. Lund Univ., 1979), 20-22.

40 Almqvist et al. Vad folket byggde, 60 . 
41 In 1964, there were 38.2 million registered cinema visits, which corresponds to 4.9 visits per capita. Cinema-going continued to decline and reached 22.9 million in the season of 1972-73, which corresponds to 2.8 visits per capita for that season. SOU 1973:53, 97. Samhället och filmen 4 [State Public Report].

42 Jon Asp, Film för folket. Om Folkets Hus och filmen (Stockholm, Premiss förlag, 2014), 230.

43 Furhammar, Filmen i Sverige, 88; Olsson, Svensk spelfilm, 12-19; Jan Reinholds, Bio i Sverige 1900-1975: marknad för fotografiska skådespel (Lerum: Reinholds, 1987), 66-67.

44 SF Bio was part of Nordic Cinema Group, which in turn was owned to $70 \%$ by the British, private-equity company Bridgepoint. SF Bio also owned 50\% of Svenska Bio, which had around 17\% of the market. Smaller, private companies owned around eight percent; the rest belonged to societies. Ds2015:31, 37. Framtidens filmpolitik. [State Public Report].

45 Sandrew. Den lilla biografen, 1969. Company Report kept at The Swedish Film Institute Library.

46 Klas Freund, Bengt Haslum, Göran Lindgren, Sandrews: de första femtio åren: en krönika (Stockholm: Norstedt, 1988), 33-35.

47 Furhammar, Filmen i Sverige, 346.

48 For the year 1966, the number of cinemas calculated here might be slightly higher than they in fact were. According to a government report, some exhibitors with few screenings (three of less per week), ceased their operations before they officially closed. SOU 1973:53, 94.

49 Leslie J. King, Statistical Analysis in Geography (Englewood Cliffs, N.J.: Prentice-Hall, 1969).

50 SOU 1973:53, 95-96; Ds 2015:31, 37.

51 MatsLundmark,“IndustrinsutvecklingiBergslagen1960-1980,"[Thedevelopmentofmanufacturingemployment intheBergslagenregion1960-1980](Uppsala,Sweden:DelstudieinomBergslagsprojektet.ForskningsrapportNr 92 från Kulturgeografiska institutionen, Uppsala universitet, 1987); Mats Lundmark and Anders Malmberg, "IndustrilokaliseringiSverige-regionalochstrukturellförändring,"[IndustrialLocationinSweden-Regionaland StructuralChange](Uppsala,Sweden:GeografiskaRegionstudierNr 19,Kulturgeografiskainstitutionen,Uppsala universitet, 1988).

52 Judith Thissen, “Multifunctional Halls and the Place of Cinema in the European Countryside, 1920-1970,” CiNéMAS 27, no. 2-3 (Spring 2017): 91-111; 96, https://doi.org/10.7202/1045369ar.

53 Thissen, "Multifunctional Halls," 97.

54 Cf. Åsa Jernudd, "Spaces of Early Film Exhibition in Sweden, 1897-1911” in Cinema Audiences and Modernity: New Perspectives on European Cinema History, eds. Daniël Biltereyst, Richard Maltby and Philippe Meers, (London: Routledge, 2012). 
55 See for example, Philippe Meers and Daniël Biltereyst, "Film Culture beyond the Big City: Cinema-Going in the Provincial and Rural Periphery of Antwerp” in Rural Cinema Exhibition, eds. Treveri Gennari et al. $135-154 ; 138$.

56 Myndigheten för kulturanalys. Faktablad 2020:1. Tillgängligheten till biografer I Sverige, 2020-06-17, https://kulturanalys.se/wp-content/uploads/2020/06/faktablad_2020_1_webb.pdf. Downloaded August 5, 2020. The Swedish Agency for Cultural Policy Analysis (Myndigheten för kulturanalys) is assigned by the Government of Sweden to evaluate, analyse and present the effects of proposals and measures taken in the cultural field.

57 Erik Amnå, "Still a Trustworthy Ally? Civil Society and the Transformation of Scandinavian Democracy," Journal of Civil Society 2, no. 1 (2006): 1-20; 10.

58 Amnå, "Still a Trustworthy Ally."

59 "About Folkets Hus och Parker," FolketsHusochParker.se. https://www.folketshusochparker.se/om-oss/ om-oss-english/

60 "Vår vision." VaraGardar.se. http://www.varagardar.se/om-oss/?top

61 "MissionandOrganisation."Filminstitutet.se.https://www.filminstitutet.se/en/about-us/swedish-film-institute/ mission-and-organisation/

62 Regeringens proposition 2015/16:132. Mer film till fler - en sammanhållen filmpolitik, 66-67.

\section{Biographies}

Åsa Jernudd holds a PhD in Cinema Studies and is associate professor in Media and Communication at Örebro University (Sweden). She is currently principal investigator of the project, Swedish Cinema and Everyday Life: A Study of Cinema-Going in Its Peak and Decline (2019-2021), financed by The Swedish Research Council. The project involves interviews with elders about memories of film and cinema in Sweden in the 1950s and 1960s, the study of cinema locations and cinema programming, as well as archival research to learn about film culture at the time.

Mats Lundmark is professor of Human Geography at Örebro University. His research interests are in the field of economic geography and in the areas of local and regional development, location analysis, local labour markets and regional policy. 


\section{TMG Journal for Media History}

Volume 23 No (1/2)/2020

\section{DOI}

https://dx.doi.org/10.18146/tmg.601

\section{PUBLISHER}

Netherlands Institute for Sound and Vision

\section{COPYRIGHT}

Each article is copyrighted (c) by its author(s) and is published under license from the author(s). When a paper is accepted for publication, authors will be requested to agree with the Creative Commons Attribution 4.0 International License. 